\title{
COMPARISON OF THE PREVALENCE OF BODY MASS DISORDERS IN 7-YEAR-OLD CHILDREN LIVING IN RURAL AND URBAN AREAS OF LOWER SILESIA IN POLAND
}

\author{
Kamila Czajka \\ ${ }^{1}$ University School of Physical Education, Faculty of Physical Education, \\ Department of Biostructure, Wroclaw, Poland
}

\begin{abstract}
Background. Body height and weight are somatic qualities largely determined by genetic factors. These qualities are also modified by the factors of external environment which have a higher impact on body mass rather than height.

Objective. The aim of the research was to identify the prevalence of disorders related to body mass / height ratio in children residing in areas of diverse population numbers. A reconnaissance of cross-environmental diversification of the BMI value was also conducted. Material and Methods. The sample consisted of 593 healthy children (314 boys; 279 girls) aged 7 from large city (Wrocław), small city (Polkowice) and rural environment (villages in the Lower Silesia) in Poland. Body height and weight were measured using standard procedures and body mass index (BMI) was calculated. Children's BMI categories were defined using IOTF cutoff points. Statistical analysis was carried out using ANOVA. Differences were considered significant at $\mathrm{p}<0.05$.

Results. The data analysis showed a general lack of significant cross-environmental and cross-gender differences in mean values of BMI among the studies girls and boys. Prevalence of children with abnormal body mass residing in areas of diverse degree of urbanisation varies from $20 \%$ to $28 \%$. Prevalence of underweight in 7 -year-old children is intensified particularly in urban environment where it occurs in a degree comparable to overweight $(9.4 \%$ vs $10.7 \%)$.

Conclusions. The observed not significant differences in BMI means in the 7-year-old children, indicate the disappearing of disproportions in basic somatic parameters between children from environments of different urbanisation degree. Underweight is found in 6\%-12\% children, which is particularly intensified in urban environment where it occurs with prevalence comparable to the phenomenon of overweight. This suggests the need to introduce intervention measures aimed at increasing the consciousness of parents in terms of effects of malnutrition in the contexts of health risks for a developing child.
\end{abstract}

Key words: children, underweight, overweight, obesity, rural and urban areas

\section{STRESZCZENIE}

Wprowadzenie. Wysokość i masa ciała to cechy somatyczne w znacznym stopniu determinowane przez czynniki genetycznie. Cechy te są modyfikowane także przez czynniki środowiskowe, które wywierają większy wpływ na masę ciała niż wysokość ciała.

Cel. Celem badań było rozpoznanie częstości występowania zaburzeń w relacji masy do wysokości ciała u dzieci zamieszkujących obszary zróżnicowane pod względem liczby mieszkańców. Przeprowadzono także rozpoznanie zróżnicowania międzyśrodowiskowego wartości wskaźnika masy ciała BMI.

Material i metody. Badaną grupę stanowiło 593 dzieci (314 chłopców i 279 dziewcząt) w wieku 7 lat pochodzących z dużego miasta (Wrocław), małego miasta (Polkowice) i obszarów wiejskich (wsie Dolnego Śląska). U badanych dokonano pomiarów wysokości i masy ciała, które posłużyły do wyliczenia wskaźnika masy ciała BMI. W celu określenia częstości występowania niedowagi, nadwagi i otyłości, użyto wartości graniczne wskaźnika BMI dla dzieci i młodzieży zaproponowane przez Cole ‘ $a$ i wsp. oraz zalecane przez IOTF. Analizę statystyczną przeprowadzono przy użyciu ANOVA. Różnice uznano za istotne statystycznie dla p $<0,05$. Wyniki. Największy procentowy udział dzieci z rozpoznaną otyłością i nadwagą (łącznie ponad 20\%) zaobserwowano w środowisku wiejskim. Największe nasilenie zjawiska niedowagi wśród dzieci badanych w poszczególnych środowiskach, zaobserwowano wśród polkowickich dziewcząt (11,9\%), a najmniejszy wśród wiejskich chłopców (5,6\%). Analiza danych wykazała na ogół brak istotnych różnic międzyśrodowiskowych i międzypłciowych w przeciętnych wartościach wskaźnika masy ciała BMI badanych dziewcząt i chłopców.

Wnioski. Różnice międzyśrodowiskowe dotyczące wskaźnika masy ciała BMI badanych dzieci 7-letnich są słabo uwidocznione, co wskazuje na zanikanie dysproporcji w podstawowych parametrach somatycznych między dziećmi ze środowisk o różnym stopniu urbanizacji. Niedowagę stwierdzono u 6\%-12\% dzieci, co jest szczególnie nasilone w środowisku

Corresponding author: Kamila Czajka, University School of Physical Education, Faculty of Physical Education, Department of Biostructure, al. I.J. Paderewskiego 35, 51-612 Wrocław, Poland, e-mail: Kamila.Czajka@awf.wroc.pl

(C) Copyright by the National Institute of Public Health - National Institute of Hygiene 
miejskim, gdzie występuje z częstością porównywalną ze zjawiskiem nadwagi. Sugeruje to potrzebę wprowadzenia środków interwencyjnych mających na celu zwiększenie świadomości rodziców w zakresie skutków niedożywienia w kontekście zagrożeń dla zdrowia dziecka.

Słowa kluczowe: dzieci, niedowaga, nadwaga, otyłość, wiejskie i miejskie obszary

\section{INTRODUCTION}

Dynamic increase of number of people with abnormalities in terms of body height / weight ratio constitutes one of the main problems of prevention of diseases of affluence. Particularly the phenomena of overweight and obesity among the population of different countries have become the main subject analysed in numerous epidemiology research, since the excess of fat tissue accumulated in the organism is often accompanied by numerous diseases such us arterial hypertension, diabetes, degenerative changes of motor system and some types of cancer $[1,2,35]$.

According to the Central Statistical Office (Statistics Poland, GUS) [12, 13, 14], prevalence of adults with identified obesity systematically increases. In the 1990s, the rate of obese men was at $10.3 \%$ of Polish population, and $12.4 \%$ for women. In 2004 , the number of obese men increased to $12.6 \%$ while the percentage of obese women remained on a level comparable to previous years $-12.5 \%$. The results of studies conducted in the following years - 2009 and 2014, show a steady and continuous increase of number of people with obesity [13, 14]. In 2009, 16.6\% of obese men were noted, while in 2014 this group constituted $18.1 \%$ of male Polish population, whereas among women the percentage of obesity increased from $15.2 \%$ to $15.6 \%$.

The problem related to the increasing number of people with excessive body weight in Poland is far more exposed in summaries concerning the identification of the phenomenon of overweight understood as a state leading to obesity. The analysis of data received in the years of 1996 - 2014 indicates that the percentage of overweight people increased in men from $18.7 \%$ to $44.1 \%$, and in women from $14.2 \%$ to $30.1 \%$. The presented data identifies men as a group of a higher risk of excess body weight prevalence. These observations seem to find confirmation also in the population of children and youth, since the results of HBSC's studies conduced in Poland in 2014 showed that the problem of increased body weight more often concerns boys (overweight - 15-16.3\%, obesity - 3.0-4.2\%) than girls (overweight $-5.5-13.6 \%$, obesity - 0.8-1.5\%) [29]. Among the leading factors contributing to the increasing number of people with excess body weight indicated are the following: increased consumption of high-calorie foods and a low level of physical activity $[3,4,19,22,31,32,34]$. In less numerous cases, excessive body mass is conditioned genetically (e.g. leptin deficiency), is endocrine-related (e.g. hypothyroidism, growth hormone deficiency) or is related to intake of a certain group of medications $[23,32]$.
Among issues concerning body mass, the phenomena of overweight and obesity are widely commented on and arise significant interest of researchers, whereas less attention is given to the problem of an insufficient body mass.

Underweight in children and youth most often results from deficiency of nutritional, energy and structural substances, and is related to the risk of disorders in psychophysical development. In children with malnutrition we often observe a significant delay of growth rate, hormonal changes in the body, delayed development, or increased risk of infections [5, 21]. Malnutrition in childhood can leave negative health effects observable also later in life.

On a global scale, the problem of insufficient body mass is exposed mainly in the context of malnutrition resulting from socio-economic conditions, an occurrence observed in people living in the countries of a low economic growth index. In highly developed countries, the problem of insufficient body mass is conditioned mainly by cultural factors, such as value system or traditions, customs and social models [5, 28]. One of the reasons behind a significant body thinness is thought to be a set of risky health behaviour inspired by current fashion related to excessive care of body, including selfperception of body mass and the resultant decisions such as reduction diets without specialist assistance, conscious and timely cessation of food consumption (so-called starvation diet), as well as reaching for pharmaceuticals assisting weight loss $[8,9,10,25,26,28]$.

In the country-wide research conducted in the years of 2007-2009 among children and youth aged $6-19$, body mass deficiency was found in $13.7 \%$ of girls and $10 \%$ of boys [15]. A similar percentage of underweight children is also indicated by the results of studies conducted in the years of 2005-2006 among children and youth of Warsaw schools, which show that insufficient body mass occurs in $13.9 \%$ of girls and $6.4 \%$ of boys (similarly to previous years of 1990 2000, respectively: $7.9 \%$ and $13.6 \%$ ) [5].

Many researchers working with identifying the significance of environmental factors on developing body highlight that larger agglomerations create more favourable conditions for the processes of growth of young generations $[17,18,21,30]$. Dynamic economic growth observable in Poland and digitalisation can contribute to decrease of multi-aspect crossenvironmental diversification.

The goal of the research was to identify the prevalence of disorders related to body mass/height ratio in children residing in areas of diverse population 
numbers. A reconnaissance of cross-environmental diversification of the BMI value was also conducted.

\section{MATERIAL AND METHODS}

The collected research material was used to conduct comparative analysis of the results of 593 children ( 314 boys and 279 girls) aged 7 ( $\bar{x}=7,07$ $\pm 0,25$ years), in public education facilities within the Lower Silesia region in Poland.

After detailed discussions with the management, applications of educational institutions for taking part in the research were accepted. The randomness of sampling was conditioned by the consent of parents or legal guardians to the participation of children in research. The research group representative of a large city comprises of children from 17 educational institutions different districts of Wrockaw, whereas the representatives of small-city environment are pupils of all first grades in primary schools located in Polkowice. The third comparative group comprises of first grade pupils of primary schools located in the villages of Legnica-Głogów Copper Belt (LGOM) such as: Brzeg Głogowski, Kotla, Kromolin, Nielubia, Rosochata, Rzeszotary, Spalona.

The results of basic somatic measurements were subjected to analysis - body height and weight, values of which were used to calculate the Body Mass Index (BMI). Children studied were dressed in light clothing and during the measurements did not wear shoes. Height was measured with anthropometer, and results were read with accuracy of $0.1 \mathrm{~cm}$. Body weight measurement were made with the use of an electronic scale, and data were recorded with the accuracy of $0.1 \mathrm{~kg}$. The results of somatic measurements are presented in Table 1. The research was conducted at the beginning of a school year and took place during the first half of the day (before noon).

Table 1. Somatic characteristic of studied children grouped according to the place of residence and gender

\begin{tabular}{|c|c|c|c|c|c|c|c|c|}
\hline \multirow{2}{*}{$\begin{array}{l}\text { Gender } \\
\text { groups }\end{array}$} & \multirow{2}{*}{$\begin{array}{l}\text { Place of } \\
\text { residence }\end{array}$} & \multirow[t]{2}{*}{$\mathrm{N}$} & \multicolumn{2}{|c|}{$\begin{array}{c}\text { Body height } \\
{[\mathrm{cm}]}\end{array}$} & \multicolumn{2}{|c|}{$\begin{array}{c}\text { Body weight } \\
{[\mathrm{kg}]}\end{array}$} & \multicolumn{2}{|c|}{$\begin{array}{c}\text { BMI } \\
{\left[\mathrm{kg} / \mathrm{m}^{2}\right]}\end{array}$} \\
\hline & & & $\bar{x}$ & sd & $\bar{x}$ & sd & $\bar{x}$ & $\mathrm{sd}$ \\
\hline \multirow{3}{*}{ Boys } & Big city & 83 & 124.37 & 5.20 & 24.57 & 3.61 & 15.84 & 1.73 \\
\hline & Small town & 160 & 125.10 & 5.83 & 25.64 & 5.51 & 16.25 & 2.45 \\
\hline & Villages & 71 & 123.72 & 5.49 & 25.68 & 5.67 & 16.66 & 2.08 \\
\hline \multirow{3}{*}{ Girls } & Big city & 76 & 122.68 & 4.53 & 24.35 & 4.01 & 16.12 & 2.05 \\
\hline & Small town & 143 & 123.50 & 5.79 & 24.67 & 5.11 & 16.04 & 2.25 \\
\hline & Villages & 60 & 123.20 & 5.60 & 24.42 & 4.29 & 16.02 & 2.14 \\
\hline
\end{tabular}

BMI value was subjected to classification taking into account international norms developed by Cole et al. $[6,7,11]$ and those recommended by IOTF; International Obesity Task Force (Table 2).

Identifying 6 weight-height ratio categories (3 degrees of thinness, normal body mass, overweight, obesity), enabled conducting cross-environmental comparison of children with abnormal mass proportions in relation to body height. In order to statistically characterise the chosen somatic parameters, the following values were determined: arithmetic average, standard deviation, coefficient of deviation, minimal and maximal value. A summary of mean values of the analysed somatic parameters and the BMI was made between the gender and environment groups (analysis of variance, Wilks' lambda test, post-hoc comparisons: NIR test). The determined level of result significance was $\alpha=0.05$. Calculations were conducted in the Department of Statistical Analyses of the Central Science and Research Laboratory of the University of Physical Fitness in Wrocław, with the use of Statistica software version 13 (StatSoft Polska).

Table 2. Classification of children's Body Mass Index (BMI) by age and gender

\begin{tabular}{|c|c|c|c|c|c|c|}
\hline \multicolumn{7}{|c|}{$\begin{array}{c}\text { International classification of BMI for children } \\
\text { Recommended by International Obesity Task Force (IOTF) }\end{array}$} \\
\hline $\begin{array}{c}\text { Age } \\
\text { (years) }\end{array}$ & $\begin{array}{l}\text { Thinness } \\
\text { grade } 3\end{array}$ & $\begin{array}{l}\text { Thinness } \\
\text { grade } 2\end{array}$ & $\begin{array}{l}\text { Thinness } \\
\text { grade } 1\end{array}$ & Normal range & Overweight & Obesity \\
\hline \multicolumn{7}{|c|}{ BMI cut-off points for boys } \\
\hline 6.5 & 12.45 & 13.10 & 14.04 & $14.05-17.70$ & 17.71 & 20.23 \\
\hline 7.0 & 12.42 & 13.08 & 14.04 & $14.05-17.91$ & 17.92 & 20.63 \\
\hline 7.5 & 12.41 & 13.09 & 14.08 & $14.09-18.15$ & 18.16 & 21.09 \\
\hline \multicolumn{7}{|c|}{ BMI cut-off points for girls } \\
\hline 6.5 & 12.28 & 12.90 & 13.82 & $13.83-17.52$ & 17.53 & 20.08 \\
\hline 7.0 & 12.26 & 12.91 & 13.86 & $13.87-17.74$ & 17.75 & 20.51 \\
\hline 7.5 & 12.27 & 12.95 & 13.93 & $13.94-18.02$ & 18.03 & 21.01 \\
\hline
\end{tabular}




\section{RESULTS}

The analysis of values of the BMI in 7-year-old children in categories of underweight and overweight showed the highest percentage of subjects with excessive body weight in countryside environment (Figure 1); both in boys $(21.1 \%)$ as well as in girls $(20.0 \%)$.

The highest intensity of overweight among the children studied in each environment, was observed among girls from Polkowice (11.9\%), and the lowest among countryside boys (5.6\%).
Detailed analysis of BMI values (6 categories), enabled, among others, to observe the occurrence of obesity. The highest percentage of children studied in this category, i.e. $8.5 \%$ was found in village boys (Table 3), however an individual value of BMI - 27.77 $\mathrm{kg} / \mathrm{m}^{2}$ (significant obesity was noted in the group of Polkowice boys (Table 3). Comparisons conducted among other studied children with higher body mass showed, similarly as in the category of obesity, the highest percentage of overweight children in village environment ( $18.3 \%$ of girls and $12.7 \%$ of boys).

Table 3. Numeric and percentage characteristic of 7-year-old children in individual categories of BMI

\begin{tabular}{|c|c|c|c|c|c|c|c|c|c|c|c|c|c|}
\hline \multicolumn{2}{|c|}{ BMI Classification } & \multicolumn{2}{|c|}{$\begin{array}{l}\text { Thinness } \\
\text { grade } 3\end{array}$} & \multicolumn{2}{|c|}{$\begin{array}{c}\text { Thinness } \\
\text { grade } 2\end{array}$} & \multicolumn{2}{|c|}{$\begin{array}{l}\text { Thinness } \\
\text { grade } 1\end{array}$} & \multicolumn{2}{|c|}{$\begin{array}{c}\text { Normal } \\
\text { weight }\end{array}$} & \multicolumn{2}{|c|}{ Overweight } & \multicolumn{2}{|c|}{ Obesity } \\
\hline \multirow{13}{*}{ 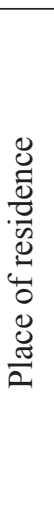 } & & $\mathrm{n}$ & $\%$ & $\mathrm{n}$ & $\%$ & $\mathrm{n}$ & $\%$ & $\mathrm{n}$ & $\%$ & $\mathrm{n}$ & $\%$ & $\mathrm{n}$ & $\%$ \\
\hline & \multicolumn{13}{|c|}{ Boys } \\
\hline & Big city & 0 & 0 & 1 & 1.2 & 7 & 8.5 & 68 & 81.9 & 5 & 6.0 & 2 & 2.4 \\
\hline & Small town & 1 & 0.6 & 3 & 1.9 & 10 & 6.3 & 124 & 77.5 & 11 & 6.9 & 11 & 6.9 \\
\hline & Villages & 0 & 0 & 0 & 0 & 4 & 5.6 & 52 & 73.2 & 9 & 12.7 & 6 & 8.5 \\
\hline & \multicolumn{13}{|c|}{ Girls } \\
\hline & Big city & 0 & 0 & 1 & 1.3 & 6 & 7.9 & 59 & 77.6 & 7 & 9.2 & 3 & 4.0 \\
\hline & Small town & 0 & 0 & 5 & 3.5 & 12 & 8.4 & 99 & 69.2 & 20 & 14.0 & 7 & 4.9 \\
\hline & Villages & 1 & 1.7 & 0 & 0 & 5 & 8.3 & 42 & 70.0 & 11 & 18.3 & 1 & 1.7 \\
\hline & \multicolumn{13}{|c|}{ Overall sample } \\
\hline & Big city & 0 & 0 & 2 & 1.3 & 13 & 8.2 & 127 & 79.9 & 12 & 7.6 & 5 & 3.1 \\
\hline & Small town & 1 & 0.3 & 8 & 2.6 & 22 & 7.3 & 223 & 73.6 & 31 & 10.2 & 18 & 5.9 \\
\hline & Villages & 1 & 0.8 & 0 & 0 & 9 & 6.9 & 94 & 71.8 & 20 & 15.3 & 7 & 5.3 \\
\hline
\end{tabular}

\begin{tabular}{|c|c|c|c|c|}
\hline & Dunderw & ight & $\square$ normal weight & \\
\hline \multirow{3}{*}{ 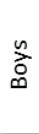 } & Big city & 9.7 & 81.9 & 8.4 \\
\hline & Villages & 5.6 & 73.2 & 21.1 \\
\hline & Small town & 8.8 & 77.5 & 13.7 \\
\hline \multirow{3}{*}{ 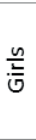 } & Big city & 9.2 & 77.6 & 13.2 \\
\hline & Villages & 10.0 & 70 & 20 \\
\hline & Small town & 11.9 & 69.2 & 18.9 \\
\hline \multirow{3}{*}{$\begin{array}{l}\overline{\bar{\sigma}} \\
\frac{\pi}{0} \\
\text { ठै }\end{array}$} & Big city & 9.4 & 79.9 & 10.7 \\
\hline & Villages & 7.6 & 71.8 & 20.6 \\
\hline & Small town & 10.2 & 73.6 & 16.2 \\
\hline
\end{tabular}

$\%$ participants

Figure 1. The structure of studied groups of 7-year-old children, taking into account the assumed main categories of BMI (underweight: combined categories of thinness $1,2,3$; overweight: combined in categories of obesity and underweight)

The lowest BMI value at $12.07 \mathrm{~kg} / \mathrm{m}^{2}$ (extreme thinness of third degree) was noted in the group of countryside girls. Whereas the highest percentage of children with low not-recommended body mass was observed in the category of the first degree of thinness (Table 3), depending on the place of residence it ranged between $5.6 \%$ (countryside boys) to $8.4 \%$ (Wrocław boys and Polkowice girls).

Data analysis showed no cross-environment and cross-gender differences in BMI values of studied girls and boys (Figure 2), while statistically significant differences were observed only between countryside and Wrocław boys (NIR test; $\mathrm{p}=0.0263$ ).

Neither were statistically significant differences obtained in the analysis of the body mass value both between environmental as well as gender groups (Figure 3), whereas body height is significantly different only between girls and boys from Polkowice (test NIR; $p=0.0118$ ), but is not a significant parameter differentiating subjects in terms of the place of residence (Figure 4).

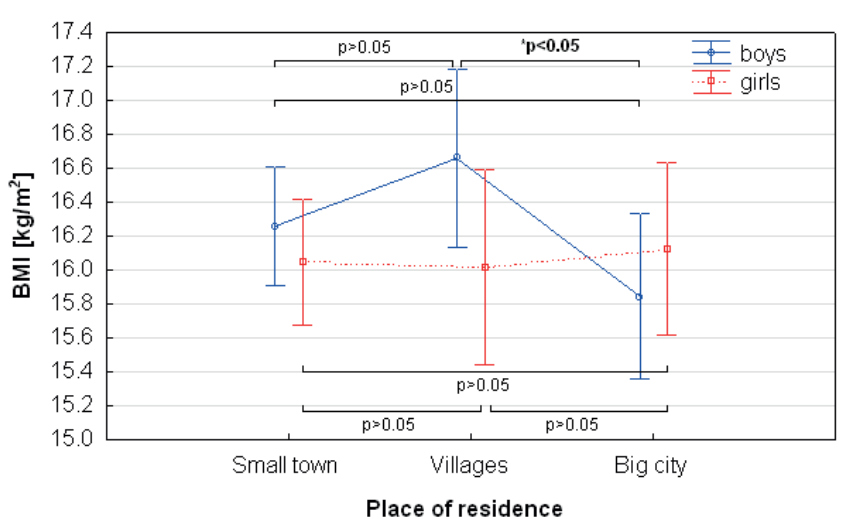

Figure 2. Body Mass Index values of 7-year-old children in the categories of gender and environment (vertical bars signify the confidence intervals of 0.95; * $\mathbf{p}<\mathbf{0 . 0 5}$ - statistically significant difference; $\mathrm{p}>0.05$ - no statistically significant difference) 


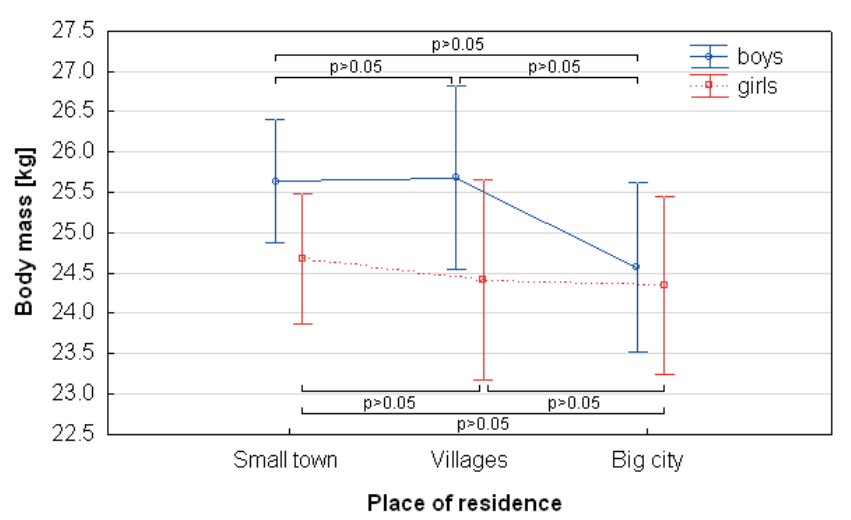

Figure 3. Body mass values of 7-year-old children in the categories of gender and environment (vertical bars signify the confidence intervals of 0.95 ; $\mathrm{p}>0.05$ - no statistically significant difference)

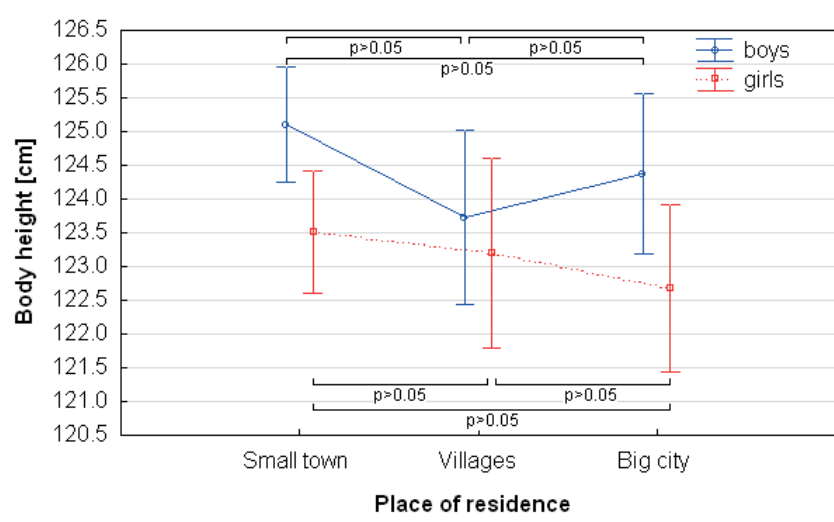

Figure 4. Body height values of 7-year-old children in the categories of gender and environment (vertical bars signify the confidence intervals of 0.95 ; $\mathrm{p}>0.05$ - no statistically significant difference)

\section{DISCUSSION}

The research conducted in Poland concerning the basic somatic parameters such as body weight and height and evaluation of their corresponding proportions with the use of the popular BMI, focus on aspects related to differences between gender groups [5] and broadly-understood environmental factors [21, 27] including the studied person's identification with a specific region of Poland [21, 15] or area of diverse urbanisation level [16].

The conducted analysis of weight to height proportions of 7-year-old children at the very beginning of school education, indicated prevalence of insignificant cross-environmental diversification of studied children residing in areas differing in terms of population density.

Boys from countryside environments, compared to urban groups (Polkowice, Wrocław), are characterised by a smaller height and higher body weight, which eventually has affected statistically significant differences in average values of BMI which were observed only between countryside and a city group (Wrocław).
The reasons behind such a state of affairs can be found in widely observable tendency for a decreased level of physical activity, in 7-year-old countryside children conditioned perhaps by a limited access to sport and leisure facilities or spaces facilitating engagement in diverse forms of movement [24]. It is commonly known that there are less possibilities of participation in organised sport classes due to difficulties related to the necessity to commute to larger centres. The reason can also be lack of possibility for participation in movement activities for schools and local environment for children of lower grades, and consequently spending free time passively, most often with multimedia devices commonly used for entertainment purposes [20].

The observable blurring of cross-environmental differences in Poland is visible also in the results of studies by Oblacińska et al. [27] conducted among 15 -year-old children. On the basis of the results of the studies, the place of residence was not indicated as a differentiating factor for occurrence of excessive body mass. It was determined, however, that excessive body thinness is more visible in the urban rather than rural environment, which corresponds to the results of our analysis which points to the prevalence of underweight in circa $10 \%$ of children studied from urban environment (Polkowice, Wrocław) and 7\% from rural environment.

On the basis of results of Szponar and Ottarzewski [33], a forecasted direction of changes in prevalence of underweight in further years of life presumes that we will see an increasing tendency in girls before puberty (ca. 12-years-old), whereas in boys together with advance of physiological maturing and growth processes, number of children with body mass deficiency will decrease.

Among the 7-year-olds studied, the highest percentage of the most desired (mainly for health reasons) body mass / height proportions was observed in children residing in a large city area (Wrocław). Almost $82 \%$ of boys and over $77 \%$ percent of girls in the studied development period (early school years) are characterised by the normal body mass. As shown by the results of studies by Gurzkowska et al. [16], it is the group of city boys who in the following years of life, i.e. the period of school education, will be exposed to the risk related to excessive body weight, and thus will require increased attention in taking up preventive measures.

\section{CONCLUSIONS}

1. In each of the Lower Silesia environments (Polkowice, LGOM villages, Wrocław) there were children characterised by abnormal body mass not-recommended for health reasons. These 
children, both in the scope of increased body mas (overweight and obesity) as well as in very low values thereof (not-recommended thinness) comprised from $20 \%$ to $28 \%$ of studied population. The scale of observed occurrence indicates the need for education among parents and teachers about the objective methods of evaluation of human body proportions and importance of the children's body proportions for current and future health condition.

2. The phenomenon of underweight is particularly intensified in urban environment where it occurs with prevalence comparable to the phenomenon of overweight, which suggests the need to introduce intervention measures aimed at increasing the consciousness of parents in terms of effects of malnutrition in the contexts of health risks for a developing body.

3. Cross-environmental differences (large city, small city, village) concerning of medium values of the body mass index of the studied 7-year-old children are not prominent.

\section{Conflict of interest}

The author declare no conflict of interest.

\section{REFERENCES}

1. Abitbol CL, Rodriguez MM.: Obesity-related nephropathy in children. Pediatr Health 2009; 3(2):141-53.

2. Abramowicz P., Konstantynowicz J., PiotrowskaJarzębskaJ.D.: Wpływ otyłości na szkielet i metabolizm kostny w okresie wzrastania i rozwoju [Relationships between fat and bone during growth]. Pediatr Med. Rodz. 2013;9(4):338-349 (in Polish).

3. Dolipska A., Majerczyk M., Góra A., Janion K., Szczepańska E.: Eating behaviours of primary school pupils from Śląskie, Małopolskie and Opolskie voivodeships in Poland. Rocz Panstw Zak Hig 2018; 69(2):193-201.

4. Dubois L., Farmer A., Girard M., Peterson K.: Regular sugar-sweetened beverage consumption between meals increases risk of overweight among preschool-aged children. J AM Diet Assoc 2007; 107(6):924-934.

5. Chabros E., Charzewska J., Wajszczyk B., Chwojnowska Z.: Częstość występowania niedoborowej masy ciała u młodzieży warszawskiej w wieku pokwitania w ostatnich 3 dekadach [Frequency of underweight in Warsaw adolescents in the last 3 decades]. Probl Hig Epidemiol 2011;92(1):99-102 (in Polish).

6. Cole T.J., Bellizzi M.C., Flegal K.M., Dietz W.H.: Establishing a standard definition for child overweight and obesity worldwide: international survey. BMJ 2000; 320(7244): 1240-1243.

7. Cole T.J., Flegal K.M., Nicholls D., Jackson A.A.: Body mass index cut offs to define thinness in children and adolescents: international survey. BMJ 2007;335(7612):194-197.
8. Czajka K., Fiszer K., Kołodziej M.: The relation between selected health behaviour and body mass index amongst adolescents living in urban and rural areas in south-western Poland. Rocz Panstw Zak Hig 2013;64(2):135-141.

9. Czajka K. Kochan K.: BMI a wybrane zachowania zdrowotne uczniów szkół podstawowych i gimnazjalnych. [Body Mass Index and selected health behaviours in pupil sof primary and secondary schools]. Probl Hig Epidemiol 2012;93(3):551-557 (in Polish).

10. Czajka K., Kochan K: Zachowania zdrowotne dzieci i młodzieży związane $\mathrm{z}$ postrzeganiem w własnej proporcji ciała. [Health behaviours in children and youth based on perception own's proportions of body] Rocz Panstw Zak Hig 2011;62(1):101-107 (in Polish).

11. Fugiel J. Czajka K., Postuszny P., Stawińska T.: Motoryczność człowieka: podstawowe zagadnienia z antropomotoryki. Med. Pharm Polska:76-79 (in Polish).

12. Główny Urząd Statystyczny (GUS) [Statistics Poland]. Stan zdrowia ludności polskiej w 2004 r. Informacje i opracowania statystyczne. Główny Urząd Statystyczny, Warszawa 2006; 29-30,140 http:// stat.gov.pl/cps/rde/xbcr/gus/stan_zdrowia_2004.pdf [17.01.2019] (in Polish).

13. Główny Urząd Statystyczny (GUS) [Statistics Poland]. Stan zdrowia ludności polskiej w 2009 r. Informacje i opracowania statystyczne. Główny Urząd Statystyczny, Warszawa 2011; 54-56. http://stat.gov.pl/cps/rde/xbcr/gus/ ZO_stan_zdrowia_2009.pdf [17.01.2019] (in Polish).

14. Główny Urząd Statystyczny (GUS) [Statistics Poland]. Zdrowie i zachowania zdrowotne mieszkańców Polski w świetle badania EHIS 2014. Główny Urząd Statystyczny, Warszawa 2015; 5. http://stat.gov. pl/obszary-tematyczne/zdrowie/zdrowie/zdrowiei-zachowania-zdrowotne-mieszkancow-polskiw-swietle-badania-ehis-2014,10,1.html?pdf=1 [17.01.2019] (in Polish).

15. Grajda A., Kułaga Z., Gurzkowska B., Napieralska E., Litwin M.: Regional differences in the prevalence of overweight, obesity and underweight among Polish children and adolescents. Med Wieku Rozwoj 2011;15(3):258-265.

16. Gurzkowska B., Grajda A., Kułaga Z. Napieralska E., Litwin M.: Distribution of body mass index categories among polish children and adolescents from rural and urban areas. Med Wieku Rozwoj 2011;15(3):250-257.

17. Hulanicka B., Brajczewski C., Jedlińska W., Stawińska T., Waliszko A.: City-town-village: growth of children in Poland in 1988. Monographies of the Institute of Antropology Polish Academy of Sciences: 7. 1990, Wroclaw, Poland.

18. Ignasiak Z., Domaradzki J., Stawińska T., Żurek G.: Rozwój morfofunkcjonalny dzieci $\mathrm{z}$ terenów przemysłowych. [Morphofunctional development of children from industrial areas]. Studia i Monografie AWF we Wrocławiu 2002;61 (in Polish).

19. Janssen I., Katzmarzyk P.T., Boyce W.F., Vereecken C., Mulvihill C., Roberts C., Currie C., Pickett W.: Comparison of overweight and obesity in school-aged youth from 34 countries and their relationships with physical activity and dietary patterns. Obes Rev 2005; 6:123-132. 
20. Jarosz M., Wolnicka K., Kłosowska J.: Czynniki środowiskowe związane $\mathrm{z}$ występowaniem nadwagi i otyłości wśród dzieci i młodzieży. [Environmental factors associated with prevalence of overweight and obesity among children and adolescents]. Postępy Nauk Medycznych 2001;9:770-777 (in Polish).

21. Jodkowska M., Oblacińska A., Tabak I., MikielKostyra K.: Występowanie zaburzeń wzrastania i stanu odżywienia u polskich 13-latków w pierwszej dekadzie XXI wieku. [Prevalence of growth and nutritional status disorders among Polish 13-years-olds In the first decade of $21^{\text {st }}$ century]. Przegl Epidemiol 2010; 64(4): 565 - 570 (in Polish).

22. Jodkowska M., Tabak I., Oblacińska A.: Siedzący tryb życia polskich 13-latków i jego powiązania z wybranymi zachowaniami zdrowotnymi, praktykami rodzicielskimi oraz masą ciała [Sedentary behaviour 13-year-olds and its association with selected health behaviours, parenting practices and body mass]. Developmental Period Medicine, 2013;XVII(2):165173 (in Polish).

23. Jung A.: Otyłość - choroba cywilizacyjna [Obesity a lifestyle disease]. Pediatr Med. Rodz. 2014;10(3):3226232 (in Polish).

24. Kawalec A., Pawlas K.: Neighbourhood environment and overweight and obesity prevalence among local residents: A review of literature. Environ Med, 2018;21(1):45-49.

25. Kołoło H., Woynarowska B.: Samoocena masy ciała i odchudzanie się młodzieży w okresie dojrzewania [Self-perception of body mass and dieting in adolescent]. Przegl Pediatr 2004;34(3/4):196-201 (in Polish).

26. Konefat M., Czajka K.: Frequency of overweight and obesity presence among rural youth in the subjective assessment of weight and height proportions and some healthy behaviour. Polish J. Environ Studies, 2007;16(5c):265-267.

27. Oblacińska A, Kołoło H., Mazur J.: Społecznoekonomiczne uwarunkowania dysharmonii rozwoju fizycznego młodzieży 15-letniej w Polsce. [Socioeconomic determinants of physical development disorders among 15-year-olds In Poland]. Med Wieku Rozwoj 2008;12(2):549-557 (in Polish).
28. Oblacińska A., Tabak I., Jodkowska M.: Demograficzne i regionalne uwarunkowania niedoboru masy ciała u polskich nastolatków. [Demographic and regional determinants of underweight in Polish teenagers] Przegl Epidemiol. 2007;61:785-79 (in Polish).

29. Oblacińska A.: Wybrane wskaźniki zdrowia. Nadwaga i otyłość. [W:] Mazur J. (red.) Zdrowie i zachowania zdrowotne młodzieży szkolnej w Polsce na tle wybranych uwarunkowań socjodemograficznych. [Selected Health indicators. Overweight and obesity]. In: Mazur J. (ed). [Health and health behaviors of school children in Poland concerning selected sociodemographic conditions]. Wyniki badań HBSC 2014. Instytut Matki i Dziecka, Warszawa 2015;106111 (in Polish).

30. Póltorak W.: Poziom rozwoju somatycznego i motorycznego młodzieży w okresie pokwitania w środowisku małego miasta i wsi. [The level of youths somatic and motor development in the period of puberty in the environment of a small town and a village]. Antropomotoryka 2004;27:51-61 (in Polish).

31. Rajeshwari R., Yang S.J., Nicklas T.A., Berenson G.S.: Secular trends in children's sweetened-beverage consumption (1973 to 1994): the Bogalusa Heart Study. J Am Diet Assoc 2005;105(2):208-214.

32. Sikorska-Wiśniewska G.: Nadwaga i otyłość u dzieci $\mathrm{i}$ młodzieży [Overweight and obesity in children and youth]. Zywn-Nauk Technol Ja [Food. Science. Technol. Quality]. 2007;6(55):71-80 (in Polish).

33. Szponar L., Ottarzewski M.: Epidemiologia niedożywienia dzieci i młodzieży w Polsce. [Epidemiology of malnutrition In children and adolescents in Poland]. Pediatr Współcz Gastroenterologia, Hepatologia i Żywienie Dziecka 2004;6(1):13-17 (in Polish).

34. Tabak I., Oblacińska A., Jodkowska M.: Physical Activity and Sedentary Behaviour as Predictors of Adolescent Health in Rural and Urban Environments in Poland. Phys Cult Sport Stud Res, 2012;54:68-77 (in Polish).

35. World Health Organization (WHO). Obesity and overweight. Available in: http://www.who.int/ mediacentre/factsheets/fs311/en/ [17.01.2019].

Received: 24.01 .2019

Accepted: 26.03.2019

This article is available in Open Access model and licensed under a Creative Commons Attribution-Non Commercial 3.0.Poland License (CC-BY-NC) available at: http://creativecommons.org/licenses/by-nc/3.0/pl/deed.en 